\title{
DEVIATION WITHOUT CONTRADICTION IN ADOLF REINACH'S ONTOLOGY
}

\begin{abstract}
Is it possible to affirm the existence of eidetic a priori laws, if these laws can be contradicted by positive law propositions? How is it possible a deviation from a priori juridical propositions? These are the two questions to which the present paper "Deviation without contradiction in Adolf Reinach's ontology" is devoted. The aim of the paper is to analyse the relations between a priori juridical propositions and propositions of positive law as investigated by Adolf Reinach. The Author presents and illustrates Adolf Reinach's conception of conditioned a priori connections.

Keywords: A priori juridical structures, positive law propositions, ontology, deviation, contradiction.
\end{abstract}

\section{INTRODUCTION}

The aim of this paper is to analyse the relations between propositions of positive law and apriori juridical propositions as investigated by one of the founders of the phenomenological movement - Adolf Reinach (1883-1917). In my paper I will first present Reinach's conception of apriori juridical propositions and his distinction between apriori juridical propositions and propositions of positive law (§ 1). Secondly, I will consider and make explicit his three arguments against the thesis according to which there could be a contradiction [Widerspruch] between apriori juridical propositions and propositions of positive law ( $(2)$. Thirdly, I will focus on Reinach's thesis according to which between apriori juridical propositions and propositions of positive law is only possibile a deviation [Abweichung] without contradiction (§3).

\section{A PRIORI JURIDICAL PROPOSITIONS IN ADOLF REINACH}

\subsection{The concept of apriori juridical proposition}

I will start with a brief introduction to clarify what Adolf Reinach means by "a priori juridical proposition" in his work Die apriorischen Grundlagen des bürgerlichen Rechtes [The Apriori Foundations of the Civil Law], 1913.

*University of Milan, paolo.dilucia@unimi.it

${ }^{1}$ On the life and work of Adolf [Adolf Bernhard Philipp] Reinach [Mainz, 23 December 1883 - Diksmuide, 16 November 1917]: Husserl 1919; Schuhmann, Smith 1987. I mention three recent Italian works on this subject: De Vecchi 2014; Simonelli 2015; Tedeschini 2015. 
Let us consider the following two juridical propositions [Rechtssätze]:

[1] Credits may be transferred to third parties by the creditor without the debtor's knowledge.

[2] A claim is extinguished by an act of waiver.

According to Reinach, the first juridical proposition, proposition [1], expresses a contingent truth.

The truth of juridical proposition [1] is based on the validity of a rule in the German civil code of Reinach's time (the Bürgerliches Gesetzbuch $(B G B)$, which entered into force on January 1, 1900). According to this rule, credit can be transferred to third parties without the debtor knowing (Reinach 1989, 141).

The second proposition [2] also expresses a truth, but according to Reinach, it does not express a contingent truth.

According to Reinach, this is a proposition that is universally and necessarily true by virtue of the essence (eidos) or the concept of claim.

The truth of proposition [2], according to which, "a claim is extinguished by an act of waiver," Reinach states:

is grounded on the essence of the claim [im Wesen des Anspruchs] as such, and consequently applies necessarily and universally [notwendig und allgemein].2

According to Reinach, juridical proposition [2] expresses or describes an a priori law of essence [apriorisches Wesensgesetz], an eidetic a priori law, which can be intuited by anyone, without any prior knowledge of positive law. ${ }^{3}$

If we can penetrate the essence [Wesen] of juridical entities [rechtliche Gebilde]:

We see what in them is strictly according to laws; we catch connections [Zusammenhänge] similarly to what happens if we penetrate the essence of numbers [Zahlen] or geometrical figures [geometrische Gebilde]: being-like [So-Sein] is based here in the essence of the beingso [im Wesen des So-Seienden - my italics; Reinach 1989, 141].

The role of the a priori doctrine of law [apriorische Rechtslehre] outlined by Adolf Reinach is, as pointed out by Edmund Husserl, bringing to light "the many a priori truths which are at the base of every right currently in existence and merely possible" (Husserl 1919, 54-55).

Edmund Husserl goes on to say:

These truths are (as Reinach shows) a priori exactly in the sense in which the primitive axioms arithmetic or logical axioms are a priori; therefore, just like the axioms, these truths can be clearly grasped as valid truths without exceptions, prior to any experience [Erfahrung] (Husserl 1919, 54-55).

2 "Ein Anspruch erlischt durch einen Akt des Verzichtes" (Reinach 1989, 144).

${ }^{3}$ In the language of Edmund Husserl and Adolf Reinach's phenomenology, eîdos or essence [Wesen] is the name of the invariant structure of the objects of experience. 


\subsection{Two problems}

Having introduced the concept of a priori juridical proposition we can tackle two problems:

(i) the problem of the contradiction [Widerspruch] between a priori juridical propositions and propositions of positive law $(\S 2)$;

(ii) the problem of the deviation [Abweichung] of the positive law propositions from a priori juridical propositions (§. 3).

\section{THE PROBLEM OF "CONTRADICTION" BETWEEN POSITIVE LAW PROPOSITIONS AND $A$ PRIORI JURIDICAL PROPOSITIONS IN ADOLF REINACH}

\subsection{Reinach's question: "Is it possible to state the existence of $a$ priori eidetic laws if these laws can be contradicted by positive propositions of law?"}

According to Reinach, a priori eidetic laws [apriorische Wesensgesetze] described by a priori juridical propositions (juridical propositions that are true by virtue of the recurring concepts inherent in them) can be clearly observed, even without prior knowledge of positive law (Reinach 1989, 149).

Reinach notes, however, that there are a priori juridical propositions [apriorische Rechtssätze] that seem to be contradicted by positive law propositions [Sätze des positiven Rechts] established by the lawmaker.

Now, Reinach wonders if it is possible to qualify laws which can be contradicted by positive law propositions as a priori eidetic laws.

Before explaining Reinach's answer ( $§$ 1.2.), let us see three examples of positive law propositions that seem to contradict a priori propositions.

\subsubsection{First example of a positive law proposition that "contradicts" an a priori juridical proposition}

Consider the example of an a priori juridical proposition relating to the following:

[3] From a promise, a claim and an obligation arise.

The birth of claim and obligation from the act of promising is, as we have seen, as evident as a logical-mathematical axiom.

Yet, German positive law (the German Civil Code in force during Reinach's lifetime) states, in apparent contradiction with the a priori juridical proposition [3] that:

[4] A claim and an obligation shall not arise from the promise of a minor.

Reinach writes that: 
Whoever makes a promise, with it assumes an obligation [Verbindlichkeit]. The twenty-yearold can, of course, make promises of all kinds: however, a fully valid legal-positive obligation does not always arise from them [vollgültige positiv-rechtliche Verbindlichkeit] (Reinach $1989,239){ }^{4}$

\subsubsection{Second example of a positive law proposition that "contradicts" an a priori juridical proposition}

Here is the second example. Consider an a priori juridical proposition concerning the claim:

[5] A claim is extinguished by fulfilment.

The extinction of the claim through fulfilment is, as we have seen, as obvious as a logical or mathematical axiom [logisches oder mathematisches Axiom].

Yet, a rule of positive law can declare that fulfilment is a necessary, yet not sufficient condition for the termination of the claim. A second necessary condition of the extinction of this claim can be the fact that fulfilment is ascertained by the judicial authority:

[6] A claim is extinguished when fulfilment is established by the judicial authority.

Reinach writes that:

a positive law [ein positives Recht], where appropriate [zweckmäßig], can establish that some claims are only extinguished when their fulfilment has been officially approved by the local judicial office (Reinach 1989, 239).

\subsubsection{Third example of a positive law proposition that "contradicts" an a priori juridical proposition}

Here is the third, and last, of the three examples.

Consider an a priori juridical proposition relating to property:

[7] It is impossible for a relation of ownership to arise from an act of promise. ${ }^{5}$

The impossibility of a relation of ownership being born from an act of promise is as obvious as a logical-mathematical axiom.

Yet, positive law can establish, just as the Code Napoléon did, in apparent contradiction with the proposition [7], that a promise to sell a certain asset has the sale value of that asset (Art. 1589: "Promesse de vente vaut vente"). ${ }^{6}$

[8] A promise of sale is equivalent to a sale.

\footnotetext{
${ }^{4}$ In addition to the minor's promise, Reinach makes four other examples of German civil law arrangements that appear to "contradict" a priori juridical propositions: (i) the promise of a loan; (ii) the promise to donate real estate property; (iii) a promise to the public; (iv) a promise in favour of a third party.

${ }^{5}$ On the normative dimensions of impossibility, see Conte, Di Lucia 2012.

${ }^{6}$ See also: Di Lucia 2013.
} 
For each of the a priori juridical propositions - Reinach warns - one can contrast a positive law proposition that seems to "contradict" the a priori juridical proposition.

But can one affirm the existence of eidetic a priori laws if these eidetic a priori laws can be "contradicted" by positive law propositions (Reinach 1989, 239)?

It appears to be an insurmountable aporia, but for Reinach, it is not.

\subsection{Reinach's answer: the thesis of deviation [Abweichung] without contradiction [ohne Widerspruch].}

To the question "Is it possible to affirm the existence of a priori eidetic laws if these a priori eidetic laws can be "contradicted" by propositions of positive law?" (§ 2.1.), Reinach answers affirmatively.

It is possible because, according to Reinach,

between our eidetic laws and the propositions of positive law we cannot speak of a true contradiction [ein echter Widersrpuch] (Reinach 1989, 241). ${ }^{7}$

According to Reinach, the positive law propositions cannot in any way contradict [widersprechen] a priori juridical propositions, but they can nonetheless deviate [abweichen] from a priori juridical propositions. ${ }^{8}$

To substantiate this thesis, which I will call the thesis of "deviation without contradiction", Reinach formulates three increasingly radical topics: a syntactic argument (§ 2.2.1.), a semantic argument (§ 2.2.2.), a pragmatic argument (§ 2.2.3.).

\subsubsection{First argument: the syntactic argument}

Firstly, Reinach puts forward an argument supporting his own theory (the theory of deviation without contradiction), a syntactic argument.

According to Reinach, between the positive law propositions and a priori juridical propositions, no real contradiction is possible because the condition for the existence of a contradiction between propositions is that the propositions that contradict each other, besides having the same content, are homogeneous, i.e. have the same structure (Reinach 1989, 240). ${ }^{9}$

However, the positive law propositions law and a priori juridical propositions are not homogeneous: they do not have the same structure, they are not isomorphic.

\footnotetext{
${ }^{7}$ The regulation [Bestimmung] presupposes a person who issues it (Reinach 1989, 242).

${ }^{8}$ The distinction between contradiction [Widerspruch] and deviation [Abweichung] in Reinach is already reported in 1960 (Schambeck 2014, 9).

${ }^{9}$ Reinach recognizes the existence of various types of propositions: assertive propositions, normative propositions, interrogative propositions, imperative propositions, propositions of promise, etc.
} 
The structure of a positive law proposition (for example, a proposition of the BGB) is typically the structure of a regulation [Bestimmung], which is expressed in terms of shall: " $A$ shall be $B$ " ["A soll B sein"].

The structure of an a priori juridical proposition, on the contrary, is typically the structure of a judgment [Urteil], which is expressed in terms of being: "A is $B$ " [“A ist B"].

Regulation [Bestimmung] and judgment [Urteil] are two entities that do not have a homogeneous structure.

Let's now return to the example of the promise.

The German Civil Code $(B G B)$ from Reinach's time states that:

[4] A claim and an obligation shall not arise from the promise of a minor.

The positive law proposition [4] expresses a regulation [Bestimmung] (a negative regulation) in deontic terms, a Bestimmung in terms of shall [sollen], whose structure is not homogeneous to the structure of the a priori juridical proposition in adeontic terms:

[3] From a promise, a claim and an obligation arise.

Indeed, this last proposition, the a priori juridical proposition [3] expresses a judgment [Urteil] in terms of being [Sein]: it is in adeontic terms.

Therefore, according to Reinach there cannot be a true contradiction between the positive law proposition (in deontic terms) [4], and the a priori juridical proposition (in adeontic terms) [3].

\subsubsection{Second argument: the semantic argument}

Secondly, Reinach supports his thesis by advancing an argument that is no longer syntactic but semantic (the thesis of deviation without contradiction).

According to Reinach, between the propositions of positive law and a priori juridical propositions, a real contradiction is not possible because the condition of possibility of the contradiction between two propositions is that the two propositions, besides having the same content and the same structure, are also subject to being true or false.

\subsubsection{Propositions of positive law are not apophantic}

For Reinach, a priori juridical propositions [apriorische Rechtssätze] are theoretical judgments [Urteile], which describe an existing reality, and as such they are susceptible to being true or false (a priori propositions are apophantic propositions).

This does not happen with the positive law propositions. The positive law proposition [Sätze des positiven Rechts] are not judgments [Urteile], which describe a reality that is existent in itself (Reinach 1989, 244).

According to Reinach, the positive law propositions belong to the category of propositions [Sätze] that Reinach calls regulations [Bestimmungen]. 
Bestimmungen do not adapt to the real existent in itself, but (thetically) establish their content [Inhalt] as having to be [als seinsollend] with the aim of adapting a previously non-existent reality to themselves (Reinach 1989, 24).

As such, the positive law propositions are not liable to be true or false (the positive law propositions are non-apophantic propositions, anapophantic propositions). Unlike a priori juridical propositions, they are beyond true and false [jenseits des Gegensatzes von wahr und falsch].

In the case of positive law propositions, Reinach writes that:

what we have is not a state of being [Setzung eines Seins] which (depending on the existence or the absence of this being) may be true or false, but a regulation [Bestimmung] that is beyond the contrast between true and false [jenseits des Gegensatzes von wahr und falsch] (Reinach $1989,240) .{ }^{10}$

\subsubsection{Propositions of positive law do not express judgments}

The possibility of clearly distinguishing between propositions that express thetic regulations [Bestimmungen] (like the positive law propositions) and propositions that express theoretical judgments [Urteile] (like a priori juridical propositions) is not, according to Reinach, disproved by the fact that sometimes the positive law proposition of can have a linguistic formulation that is identical to that of propositions that express judgments [Urteile]. There is an irreducible semiotic difference (a difference that is both semantic and pragmatic).

Reinach writes:

The proposition [der Satz] "Man's legal capacity is acquired from the moment of birth" [Die Rechtsfähigkeit des Menschen beginnt der der Vollendung der Geburt] [...] cannot be considered a judgment [Urteil]. [...]

The proposition "Man's legal capacity is acquired from the moment of birth" can be found in a textbook of civil law. The words are the same, but the content [Gehalt] of the proposition [Satz] is obviously different [from the content of the proposition-of-regulation [Bestimmungssatz] contained in the German Civil Code].

With the civil law textbook, one really is faced with a judgment [Urteil], one can state that, at present, man's legal capacity in Germany begins with birth; this statement refers to article 1 of the German Civil Code, which is where it is established.

However, this article does not contain a claim [Behauptung] (it would be difficult to establish a judgment by means of an identical judgment), but a regulation [Bestimmung]. Since the Civil Code states that the people's legal capacity is acquired at birth, on the basis of this judgment [auf Grund dieser Bestimmung], the lawmaker can say that things are like this in Germany (Reinach 1989, 240-241).

${ }^{10}$ On judgments and norms in Reinach, see Alves 2015. 
With the distinction between (anapophantic) positive law propositions that express regulations established by lawmakers and homonym (apophantic) legal propositions expressing judgments established by jurists, Reinach envisages a distinction that is of great importance for the philosophy of law: the Kelsenian distinction between Sollnorm and Sollsatz. ${ }^{11}$

\subsubsection{Third argument: pragmatic argument}

Thirdly, Reinach puts forth a third argument to support his theory (the theory of deviation without contradiction) that is non-syntactic, non-semantic, but pragmatic.

According to Reinach, between the positive law propositions of and a priori juridical propositions, a true contradiction is not possible because a condition of possibility of the contradiction between propositions is that the propositions that contradict each other are pragmatically equivalent.

But the positive law propositions (which are the objectification of regulations [Bestimmungen]) and a priori juridical propositions (which are the objectification of claims [Behauptungen]) are not pragmatically equivalent.

The pragmatic function of the regulation [Bestimmung] is clearly distinguished, according to Reinach, from the pragmatic function of judgment [Urteil].

Reinach writes:

A regulation [der Bestimmung] is one [...] of those acts, those efficacious acts [wirksame Akte], which with their enforcement [Vollzug] intend to bring about [beWirken] change [Veränderung] in the world and potentially do indeed provoke it. Each judgment is aimed at the realisation [Realization] of what it presents as having to be [als seinsollend]. The content of a judgment can never be something that is necessary a priori [a priori notwendig], or impossible a priori [a priori unmöglich]. ${ }^{12}$

\section{THE PROBLEM OF THE "DEVIATION" OF THE POSITIVE LAW PROPOSITIONS FROM A PRIORI JURIDICAL PROPOSITIONS IN ADOLF REINACH}

\subsection{Reinach's question: "How is a deviation of the positive law propositions from a priori juridical propositions possible?"}

Having denied the possibility of there being a contradiction between the positive law propositions and a priori juridical propositions [Widerspruch],

${ }^{11}$ On the distinction between Sollsatz and Sollnorm in Hans Kelsen, see Kelsen 1960.

${ }^{12}$ A systematic investigation of the theory of regulation [Bestimmung] by Adolf Reinach was carried out by the Alsatian-born and naturalised U.S. citizen philosopher Herbert Spiegelberg [1904-1992], in: Spiegelberg 1935. See Paulson 1990, Di Lucia 2008. 
Reinach asks himself about the deviation [Abweichung] of the positive law propositions from a priori juridical propositions.

Let us once again consider the positive law proposition [der Satz des positives Rechts] regarding the promise made by a minor.

[4] A claim and an obligation shall not arise from a promise made by a minor.

Between the proposition [4] and the proposition [3]

[3] From a promise, a claim and an obligation arise.

there cannot be a genuine contradiction [Widerspruch] for the reasons we have seen in $\S 2$ eidetic connections.

However, the positive law proposition [4] constitutes an open deviation [Abweichung] from the a priori proposition [3].

On the one hand, Reinach observes, it is perfectly sensible [sinnvoll] for the lawmaker to deviate from the a priori proposition [3], establishing the positive law proposition [4].

Indeed, Reinach writes:

Just as there would be no sense [sinnlos] in saying that a claim, which arises out of a necessity of essence [wesensnotwendig] from the promise, should not be born [erwachsen], on the other hand, the proposition [der Satz] according to which it is not right, and should not be, that the carelessness or inexperience of a young person is exploited by others $[d a \beta$ es nicht recht sei und nicht sein solle daß der Leichtsinn oder die Unerfahrenheit eines jungen Menschen durch andere ausgenützt wird] would be more than sensible [sinnvoll]: his rash promise should not be [soll nicht sein] and therefore, likewise the claims and obligations that such a rash promise derive from should do not have to be out of necessity [notwendig] (Reinach 1989, 248).

On the other hand, Reinach points out that the juridical proposition [3] "From a promise a claim and an obligation arise" is an a priori proposition, universally and necessarily valid just as much as a mathematical proposition is (e.g. $2 \times 2=4)$.

Therefore, a positive law proposition (a legal ruling) deviating from the a priori juridical proposition [3] would in principle be impossible [unmöglich], just as much as a positive law proposition (a legislative regulation) would be if it stated that 2 × $2=5$ (Reinach 1989, 241).

How is it possible - Reinach then asks himself - that the lawmaker could establish the proposition [4] "A claim and an obligation shall not arise from the promise of a minor"?

More generally: How is the deviation [Abweichung] of a priori juridical propositions possible (Reinach 1989, 241)?

In order to answer this question Reinach introduces a fundamental distinction that I will make explicit in $\S 3.2 .:$ the phenomenological distinction between two kinds of eidetic connections. 


\subsection{Reinach's answer: the theory of the conditioned nature of all $a$ priori juridical connections}

Reinach's answer to the question "How is deviation [Abweichung] of the positive law propositions law from a priori juridical propositions possible?" is as follows: the deviation [Abweichung] from a priori juridical propositions is possible because all valid eidetic connections within the juridical framework belong to a particular species of eidetic connections whose validity [Gültigkeit] is conditioned (Reinach 1989, 250).

Paragraph 3.2.1. is dedicated to the genus and the two species of conditioned eidetic connections.

\subsubsection{Two species of eidetic connections: unconditional eidetic connections vs. conditioned eidetic connections}

According to Reinach, two species of eidetic connections [Wesenszusammenhänge] are given:

(i) unconditioned eidetic connections;

(ii) conditioned eidetic connections.

The distinction between the two types of eidetic connection (formulated by Reinach in the third chapter of his book Die apriorischen Grundlagen des bürgerlichen Rechtes, 1913), is also valid beyond the juridical domain.

According to Reinach:

In general, we can distinguish two types [zwei Typen] of eidetic connections [Wesenszusammenhänge]: the eidetic connections that are valid [gelten] indiscriminately in all circumstances [unter allen Umständen], and the eidetic connections that are valid only on the condition [unter der Voraussetzung] that certain facts are not involved [Tatbestände] (Reinach $1989,250$.

According to Reinach, the first type of eidetic connection has unconditioned validity. It is illustrated by the following example:

[9] There is no color without extension.

There are strictly no circumstances in which a color can exist without extension.

On the other hand, according to Reinach, the second type of eidetic connection has a conditioned validity. It is illustrated by the following example:

[10] The fulfilment of a desire provides pleasure.

Let us speculate, Reinach remarks, that the fruit we have wanted to try has an extremely bitter taste. It is therefore possible that the satisfaction of a desire does not cause that pleasure which that experience tends to provide.

Here is Reinach's complete passage:

The proposition according to which the fulfilment of a desire [Strebenserfüllung] provides pleasure [Lust] is to be linked to the second class [the class of conditioned eidetic connections]. 
Indeed, this proposition it is not achieved through prolonged observation, but rather it serves as a guide to our observations (as a proposition based on the very essence of the fulfilment of desire [im Wesen der Strebenserfüllung]). The validity [Gültigkeit] of the proposition "The fulfilment of a desire procures pleasure", which in itself is without exception, may however be eliminated [ausgeschaltet] in certain circumstances. It is possible, for example, that if the fruit we wanted to taste is extremely bitter, then that fruit will not cause any pleasure (Reinach $1989,250) \cdot{ }^{13}$

Thus far, Reinach makes a general distinction between two types of eidetic connections, only the second of which can be excluded in certain circumstances, if certain facts occur.

But the general distinction between two types of eidetic connection is the premise for one of Reinach's important theories: the theory of the conditioned nature of all the valid eidetic connections within the juridical framework.

\subsubsection{A priori juridical connections as conditioned connections}

Having introduced the general distinction between two types of eidetic connections, Reinach states that the valid eidetic connections within the juridical framework are all conditioned eidetic connections.

Indeed, according to Reinach, although the eidetic connections that are valid within the juridical framework are, insofar as they are a priori, universal and necessary connections and, as such, do not admit exceptions, however, their validity [Gültigkeit] is likely to be excluded, suspended, from the validity [Geltung] in and for an order of positive law propositions established by a lawmaker. ${ }^{14}$

Let us return to the example of the minor's promise.

In the case of the minor's promise, according to Reinach, the a priori juridical proposition [3] "From a promise, a claim and an obligation arise" remains valid without exception even if the lawmaker states that [4] "A claim and an obligation shall not arise from the promise of a minor".

However, the validity of the eidetic connection described by the proposition [3] is suspended (excluded) due to the effect of the regulation [Bestimmung].

Reinach writes:

The universal eidetic connection [der allgemeine Wesenszusammenhang] is suspended [ist außer Kraft gesetzt] by means of the regulation [durch die Bestimmung], not in the sense that it no longer exists [nicht mehr besteht], but in the sense that that universal eidetic

${ }^{13}$ On the nature of the "Reinachian synthetic a priori" see: Zełaniec 1992, Zełaniec 2012.

${ }^{14}$ In the third chapter of the book Die apriorischen Grundlagen des bürgerlichen Rechtes [The Apriori Foundations of the Civil Law], 1913, Reinach distinguishes the conditions of validity [Gültigkeit] of a priori juridical propositions [apriorische Rechtssätze] from the conditions of validity [Geltung] in and for a system of positive law propositions [Sätze des positiven Rechts]. See: Di Lucia 1997, 121-122. On the relationships between logical validity and legal validity, see: Kelsen 1965; Conte 1998. 
connection (connection [Zusammenhang] which exists in itself and for itself [an und für sich] and whose validity [Gültigkeit] is in fact assumed [vorausgesetzt ] from the deviant regulation [abweichende Bestimmung]) is excluded [ausgeschaltet] from the regulation itself (Reinach 1989, 250).

\section{CONCLUSION}

The possibility that an eidetic connection, a universal and necessary eidetic connection, that is grounded on an essence [Wesen], may be excluded [ausgeschaltet] by a legislative regulation, is far from being an accidental possibility; according to Reinach, it is an eidetic possibility, inscribed in the nature of juridical connections, and constitutes a specific and differential feature of the ontology of the "law" region (within the ontology of law), an ontology that runs alongside other regional ontologies (e.g. the ontology of numbers), see: Di Lucia, forthcoming.

(Translation from Italian language by Gaea Vilage).

\section{BIBLIOGRAPHY}

Alves, Pedro S. 2015. "Giudizi e norme". Rivista internazionale di Filosofia del diritto 92: 25-54.

Conte, Amedeo Giovanni. 1998. "Hans Kelsen's Deontics". In Normativity and Norms. Critical

Perspectives on Kelsenian Themes. 331-341. Edited by Stanley Paulson, Bonnie Litschewski Paulson. Oxford: Clarendon Press.

Conte, Amedeo Giovanni. Paolo Di Lucia. 2012. “Adýnaton. Four Dichotomies for a Philosophy of Impossibility". Phenomenology and Mind 2: 134-143.

De Vecchi, Francesca. Ed. 2014. Eidetica del diritto e ontologia sociale. Il realismo di Adolf Reinach. Milan: Mimesis.

Di Lucia, Paolo. 1997. L'universale della promessa. Milan: Giuffrè.

Di Lucia, Paolo. 2008. "Devoir adéontique: Reinach, Spiegelberg, Kelsen". In Adolf Reinach. Entre droit et phénoménologie. De l'ontologie normative à la théorie du droit. 51-57. Edited by Jocelyn Benoist, Jean-Francois Kervegan. Paris: Vrin,

Di Lucia, Paolo. 2013. "Figmentum. An Essay in Legal Ontology”. In From Fictionality to Realism. 111-123. Edited by Carola Barbero, Maurizio Ferraris, Alberto Voltolini. Newcastle upon Tyne: Cambridge Scholars.

Di Lucia, Paolo. Forthcoming. Ontologia della realtà giuridica.

Husserl, Edmund. 1919. "Adolf Reinach". Kant-Studien 23: 147-149.

Kelsen, Hans. 1965. "Recht und Logik". Neues Forum 12: 421-425, 495-500.

Paulson, Stanley L. 1990. "Remarks on the Concept of Norm". Journal of the British Society for Phenomenology 21: 3-13.

Reinach, Adolf. 1913. "Die apriorischen Grundlagen des bürgerlichen Rechtes". Jahrbuch für Philosophie und phänomenologische Forschung 1: 685-847.

Reinach, Adolf. 1989. Sämtliche Werke. Textkritische Ausgabe in 2 Bänden. Band I. Die Werke. Edited by Karl Schuhumann, Barry Smith. München: Philosophia. 
Schambeck, Herbert. 2014. "Der Begriff der Natur der Sache”. In Sein und Sollen. Grundfragen der Philosophie des Rechts und des Staates. 3-27. Edited by Heribert Franz Köck, Cristina Hermida of Llano, Antonio Incampo, Andrzej Szmyt. Berlin: Duncker \& Humblot.

Schuhmann, Karl. Barry Smith. 1987. "Adolf Reinach. An Intellectual Biography”. In Speech Act and Sachverhalt. Reinach and the Foundations of Realist Phenomenology. 3-27. Edited by Kevin Mulligan. Dordrecht: Martinus Nijhoff.

Simonelli, Maria Ausilia. 2015. "Il primo e l'ultimo Reinach". In Sul concetto di causalità nel diritto penale. 7-49. Edited by Adolf Reinach. Naples: Edizioni Scientifiche Italiane.

Spiegelberg, Herbert. 1935. Gesetz und Sittengesetz. Zürich: Niehans.

Tedeschini, Marco. 2015. Adolf Reinach. La fenomenologia, il realismo. Macerata: Quodlibet.

Żełaniec, Wojciech. 1992. "Fathers, Kings, and Promises. Husserl and Reinach On the A Priori". Husserl Studies 9: 147-177.

Żełaniec, Wojciech. 2012. "Reinach's Synthetic A Priori. An Attempt at a Refutation". In Eidetica del diritto e ontologia sociale. Il realismo di Adolf Reinach. 59-82. Edited by Francesca De Vecchi. Milan: Mimesis. 